\title{
"Peculiarities of functioning of financial and credit mechanism for performing leasing operations in developed countries and in Ukraine"
}

\begin{tabular}{|c|c|}
\hline AUTHORS & $\begin{array}{l}\text { Anzhela Ya. Kuznyetsova } \\
\text { Natalia I. Kozmuk } \\
\text { Olexandr A. Levchenko }\end{array}$ \\
\hline ARTICLE INFO & $\begin{array}{l}\text { Anzhela Ya. Kuznyetsova, Natalia I. Kozmuk and Olexandr A. Levchenko (2017). } \\
\text { Peculiarities of functioning of financial and credit mechanism for performing } \\
\text { leasing operations in developed countries and in Ukraine. Problems and } \\
\text { Perspectives in Management, 15(4), 209-221. doi:10.21511/ppm.15(4-1).2017.05 }\end{array}$ \\
\hline DOI & http://dx.doi.org/10.21511/ppm.15(4-1).2017.05 \\
\hline RELEASED ON & Monday, 25 December 2017 \\
\hline RECEIVED ON & Wednesday, 04 October 2017 \\
\hline ACCEPTED ON & Wednesday, 13 December 2017 \\
\hline LICENSE & $\begin{array}{l}(c) E Y \\
\text { This work is licensed under a Creative Commons Attribution } 4.0 \text { International } \\
\text { License }\end{array}$ \\
\hline JOURNAL & "Problems and Perspectives in Management" \\
\hline ISSN PRINT & $1727-7051$ \\
\hline ISSN ONLINE & $1810-5467$ \\
\hline PUBLISHER & LLC "Consulting Publishing Company "Business Perspectives" \\
\hline FOUNDER & LLC “Consulting Publishing Company "Business Perspectives" \\
\hline
\end{tabular}

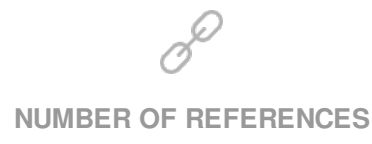

27

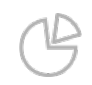

NUMBER OF FIGURES

1
ニニ:-

NUMBER OF TABLES

3

(C) The author(s) 2023. This publication is an open access article. 


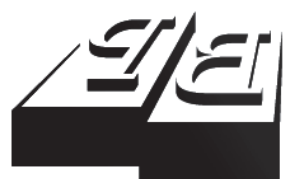

BUSINESS PERSPECTIVES

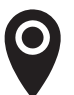

LLC "CPC "Business Perspectives" Hryhorii Skovoroda lane, 10, Sumy, 40022, Ukraine

www.businessperspectives.org

Received on: 4th of October,2017 Accepted on: $13^{\text {th }}$ of December, 2017

(C) Anzhela Ya. Kuznyetsova, Natalia I. Kozmuk, Olexandr A. Levchenko, 2017

Anzhela Ya. Kuznyetsova, Doctor of Economics, Professor, First Vice Rector, State Higher Education institution "University of Banking", Ukraine.

Natalia I. Kozmuk, Ph.D., State Higher Education Institution "University of Banking”, Ukraine.

Olexandr A. Levchenko, Postgraduate Student, State Higher Education Institution "University of Banking", Ukraine.

Anzhela Ya. Kuznyetsova (Ukraine), Natalia I. Kozmuk (Ukraine),

Olexandr A. Levchenko (Ukraine)

\title{
PECULIARITIES OF FUNCTIONING OF FINANCIAL AND CREDIT MECHANISM FOR PERFORMING LEASING OPERATIONS IN DEVELOPED COUNTRIES AND IN UKRAINE
}

\begin{abstract}
World experience shows that improving the equipment and machinery supply efficiency in all economic sectors and, thus, contributing to the country's economic growth can be achieved through the effective functioning of the financial and credit mechanism for performing leasing operations. Given that Ukrainian leasing market is at the formation stage and the economy is in the crisis, the issues of improving the leasing industry activity are extremely important for Ukraine.
\end{abstract}

Thus, the purpose of the article is to study the worldwide experience of the functioning of the financial and credit mechanism for performing leasing operations and to substantiate the need to implement new leasing tools and forms in Ukraine and the use of new financing sources for leasing operations.

It is determined that in order to improve functioning of the financial and credit mechanism for performing leasing operations in Ukraine, it is necessary to diversify financing sources of leasing operations by using institutional investors' or venture capital investors' funds and certificates, pools of securities provided with assets, which is a lease agreement. At the same time, as experience of the developed countries shows, new instruments and forms of leasing operations should be applied in Ukraine, in particular securitization, venture leasing, complex and operational leasing, which should improve the leasing industry activity. It was revealed that the secondary leasing market development in Ukraine should help to reduce the leasing companies' vulnerability to the risk of equipment price change.

During scientific research, the methods of logical generalization and scientific abstraction, the statistical method (to analyze the leasing market development in the world and in Ukraine), the graphical method (for the changing dynamics of the main indicators of Ukrainian leasing market development), the comparative analysis method (while comparing the features of the functioning of the financial and credit mechanism for performing leasing operations in developed countries and in Ukraine) have been used.

Research results provide grounds for arguing that in order to improve the leasing industry activity in Ukraine, it is necessary to improve the financial and credit mechanism for performing leasing operations directly through the tools, forms and leasing operations financing sources diversification.

\section{Keywords}

\section{JEL Classification}

leasing, leasing operations, financial and credit provision, financial and credit mechanism, leasing financing sources, leasing forms, securitization, venture leasing, venture financing, complex leasing, operational leasing

G20, G21, G23, G29

\section{(c) (1)}

This is an Open Access article, distributed under the terms of the Creative Commons Attribution 4.0 International license, which permits unrestricted re-use, distribution, and reproduction in any medium, provided the original work is properly cited.

\section{INTRODUCTION}

World practice shows that in recent years, the volume of leasing operations is increasing, and their share in GDP is increasing as well. The developed countries, in particular the USA, Canada, Great Britain, Germany, Japan, Australia, have been using leasing as a source of 
economic growth. At the same time, they have a well-developed financial and credit mechanism for performing leasing operations characterized by diverse tools and forms, including securitization, venture leasing, complex leasing, leasing financing methods, in particular, financing guarantees by the European Fund for Strategic Investments (EFSI), which is a part of the financing program for lessors who lend money to small and medium-sized businesses.

The financial and credit mechanism for performing leasing operations is considered as a set of methods (planning and forecasting, provision (lending, budgeting, investing, taxation, insurance, franchising, factoring, discounting, etc.), financial regulation and financial control), instruments (direct, indirect), levers (incentives, sanctions), forms (self-financing, state financing, loan capital) and financial, organizational, technical and technological, institutional, informational, regulatory support. Herewith the mechanism's action should be aimed at achieving the balance between the leasing operations market, the business sector's needs and the opportunities of the financial and credit market.

Ukrainian leasing market is at the initial stage of formation, where bank loans are the main sources of leasing financing. The experience of developed countries has shown that with the help of leasing, it is possible to update the enterprises' fixed capital in short terms, to increase the innovative production volume and in such a way to promote economic growth of the country. In this regard, it is necessary to study the features of financial and credit mechanism for performing leasing operations in developed countries in order to improve the functioning of this mechanism in Ukraine, which is an actual task in the modern conditions of economic reformation.

\section{LITERATURE REVIEW}

In terms of limited consumer demand due to their insufficient solvency, the increase of the efficiency of equipment and machinery supply in all sectors of the economy, including agriculture and agroindustrial complex in general, can be achieved through the effective functioning of the financial and credit mechanism for performing leasing operations.

Nowadays, leasing is seen as the driving force behind the growth of the country's economy and boosting economic growth. In particular, Vakhitov and Zamaletdinov, while studying financial and credit mechanism for leasing operations at micro-, meso- and macro-levels in priority economic sectors, found that leasing loans as an alternative form of financing that does not require collateral in the form of property or highly liquid securities, contribute to the multiplicative impact of capital intensity, material intensity and energy efficiency, which is translated into the function of aggregated consumption. This gives the aggregate demand curve an upward orientation, and, therefore, contributes to economic growth in the noninflationary way, stimulating the developing economy (Vakhitov \& Zamaletdinov, 2015).
At the same time, Weidner (2000), while emphasizing the indirect dependence of the leasing service quality and depth on the material intensity level, suggested that since small transitive economies are characterized by rather narrow list of leasing instruments and low leasing market capitalization, then the primary task for market pre-capitalization should be funds accumulation.

Komarov (2002) also emphasized the advantages of leasing, and noted that it contributes to the implementation of new standards for energy-saving material production. Updated non-current asset reduces energy consumption over the entire life cycle of the latter, which contributes to the aggregated demand function growth.

Based on the approaches and arguments of Nair, Kloeppinger-Todd, and Mulder (2004), Olugbenga and Mashigo (2017), Frolov, Strilec, and Balatskyi (2017), it can be said that leasing is the only tool for recent scientific and technological developments implementation in manufacturing and non-manufacturing sectors and services, especially in today's difficult access to long-term bank lending, as well as it is an accelerator of economic growth. 
During the period 2015-2016, leasing in general, and in particular leasing of equipment, machinery and other property, developed at a rapid pace in the world. The volume of leasing operations in developed countries amounted to $2-5 \%$ of GDP and $15-30 \%$ of fixed assets investments in 2015, while in Ukraine, these figures were $0.5 \%$ and $2.7 \%$, respectively (Mychalchuk \& Kryvoruchko, 2015). The offer of leasing companies and banks has been satisfying the aggregate demand for leasing services by only $10 \%$, which indicates the need for further improvement of the leasing market and the financial and credit mechanism for performing leasing operations (Mychalchuk \& Kryvoruchko, 2015). According to expert estimates (Vasin Yu, 2016), in order to meet the needs of the Ukrainian economy real sector in 2017, it is necessary to provide the lease loans in the amount of over UAH 21.4 billion.

In the world economy, such method of financial and credit mechanism for performing leasing operations as investment in fixed assets ranks second after a bank loan. Looking at the source structure of leasing operations in Ukraine, the share of borrowed funds is $59.4 \%$ and the share of own funds is $40.6 \%$ (Hontar et al., 2016).

Today's world leasing services market is characterized by such indicators: annual volume of new business - about USD 450 billion. In particular, the global amount of leasing agreements in 2016 amounted to USD 415 billion, while the US share was $62 \%$ or USD 260 billion. The book value of leased property was USD 1.5 trillion in 2016 (market value - about USD 2.2-2.5 billion); the average share of leasing in gross investments in fixed assets was about $15 \%$.

According to the European Federation of Leasing Company Associations, the volume of new leasing assets in European countries amounted to USD 315 billion in 2015. The largest volumes of new leasing contracts were concluded in the United Kingdom (EUR 76.9 billion), Germany (EUR 53.2 billion), and France (EUR 43.6 billion). This figure amounted to EUR 8.2 billion in the Russian Federation, and to EUR 0.237 billion in Ukraine. As for the structure of leasing services users in $2015,43 \%$ of consumers were employed in the service sector, industry $-23 \%$, individuals - $24 \%$, agriculture and transport sector $-3 \%$ each (Growth-Internal Market, Industry, Entrepreneurship and SMEs).

In 2015,30\% of all investments in the United States were made in the form of leasing operations, in England $-28.2 \%$, in Germany - 16.6\%, in France - $17.5 \%$, in Sweden $-26.3 \%$. According to experts from the International Association of European Integration, $23.4 \%$ of small and medium enterprises in Europe used leasing during 2015, including in Poland - 39\%, in Germany - 34\%, in Italy $-32 \%$, in the United Kingdom - 7\%, in Cyprus and Montenegro - 6\% each, in Ukraine - less than 4\% (Survey on access to finance of enterprises). Such an increase of leasing operations share in the total volume of investments is due to the favorable institutional environment of leasing development and its state support.

The relevance of leasing accumulation for Ukrainian economy is due to the need to implement the strategy of the domestic producer development and to ensure the emergence of a socially-oriented restorative market economy, integrated into the world economy, which will be based on the priority of energy efficiency and production savings.

According to the World Bank research "Leasing: An Underutilized Tool in Rural Finance", the positive effect of leasing for commodity-oriented economies in the phase of industrial transformation is (Nair et al., 2004) access to the alternative source of capital financing and capital investment growth, which has declined in recent years in Europe by $15 \%$ over pre-crisis level; deepening the capital market through debt instruments for leasing financing; improving the financial services quality through increased competition.

It is known that half of the world's turnover of goods delivered through leasing is owned by the United States as a country where leasing occurred in 1950. According to the World Bank experts (Nair et al., 2004) and Ukrainian scholars (Chushak \& Mykulyak, 2014), the loss of the US economy would amount to USD 290 billion annually without the leasing industry.

Thus, the purpose of the article is to study the worldwide experience of the financial and credit 
mechanism for performing leasing operations functioning and to substantiate the feasibility of new instruments and forms of leasing implementation in Ukraine and the use of new financing sources for leasing operations.

\section{METHODS}

The following methods have been used in research: the method of logical generalization and scientific abstraction, the statistical method (to analyze the leasing market development in the world and in Ukraine), the graphical method (for the changing dynamics of the main indicators of Ukrainian leasing market development), the comparative analysis method (while comparing the features of the financial and credit mechanism for performing leasing operations in developed countries and in Ukraine).

\section{RESULTS}

There is a big gap in the evolutionary process of financial and institutional provision of leasing in Ukraine due to the lack of operation principles and tools for the development of the financial and credit mechanism for performing leasing operations and due to the underestimation of the role of leasing in the country's economy innovative development by the financial community (Figure 1). Leasing offers not only affordable credit or lease of high-speed wear out equipment, but also venture capital investment and the sophisticated mechanism for financial investment through investment assets, which greatly expands the options for replacing equipment for both small and medium-sized enterprises and large multinational corporations.

Such a gap between evolutionary development and low capitalization of the leasing industry in Ukraine can be attributed to the continued financial instability in the financial system. Currency market fall in 2010 led to the $70 \%$ decrease in the activity of lessors firstly in 2011, and the currency crisis in 2014-2015, the bankruptcy of 94 financial and credit institutions in 2014-2017 and the global recession - all this led to the following leasing market fall, which occurred in 2014, when it was concluded that there were $87 \%$ less deals than in 2013.

While studying the features of the financial and credit mechanism for performing leasing operations, scientists usually distinguish six stages (steps) of leasing development that this industry passes from the moment of its appearance to maturity, namely: stage 1 - rent; stage 2 - simple fi-

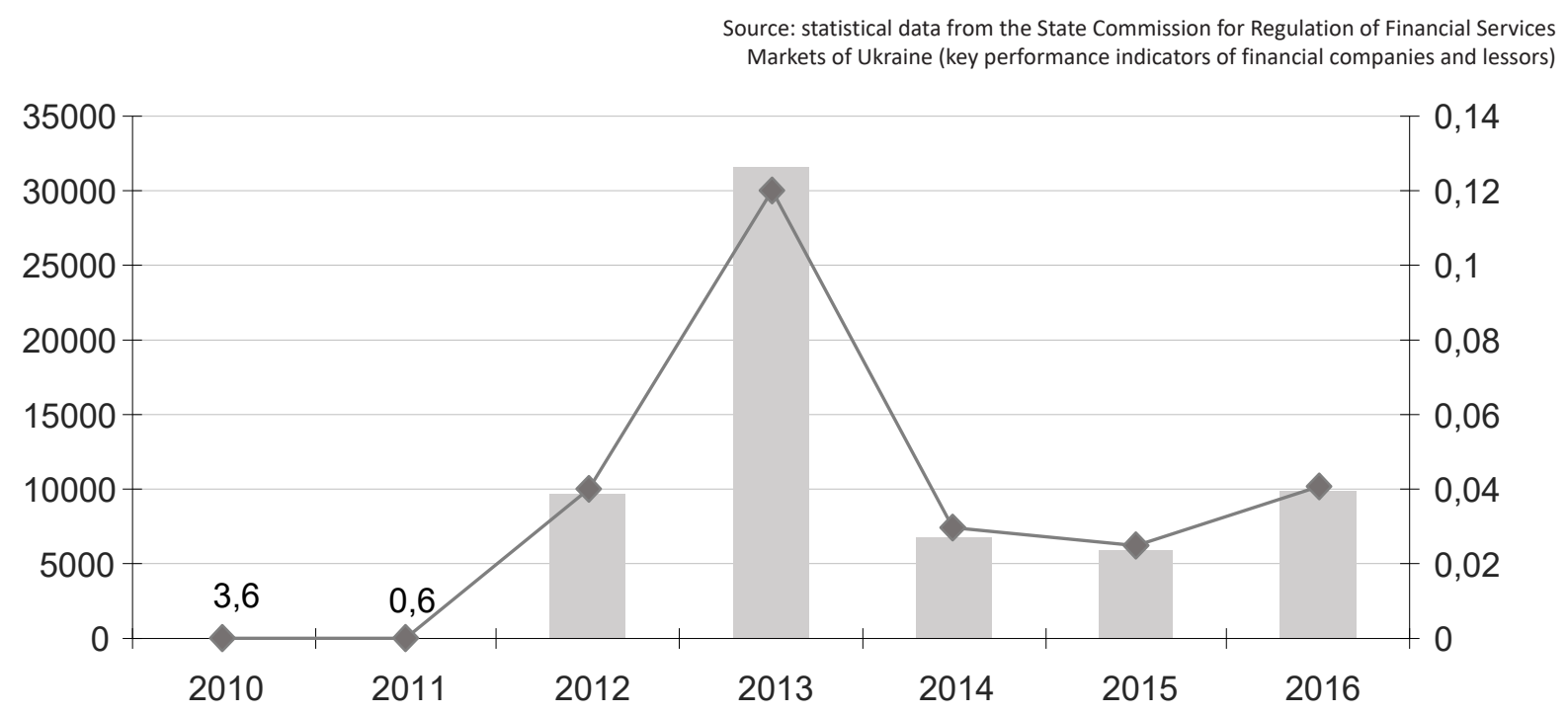

the value of financial lease agreements by legal entities-lessors (millions of hryvnias)

percentage of capital investment coverage (\%)

Figure 1. Dynamics of performed financial leasing transactions in Ukraine 
nancial leasing; stage 3 - comprehensive financial leasing; stage 4 - package services (operational leasing); stage 5 - the stage of new products; stage 6 - maturity (Nikolayeva \& Puhachenko, 2014). Thus, different countries used different methods and tools of the financial and credit mechanism for performing leasing operations at each of the above stages.

The first stage (rent) is known since ancient times and has not lost its relevance. It is characterized by the short-term nature (up to 12 months), by the full set of services, and by the return of the object to the owner after the contract expiration.

The second stage (simple financial leasing) arose and developed into an independent financial service in the middle of the 20th century in the UK and the US. A lessee, having fulfilled the terms of the agreement and having paid full lease payments, receives the opportunity to buy at the nominal price the leased asset, which a lessor does not seek to return. A lessee is characterized by the property psychology. A lessor is limited mainly to the fixed asset financing through leasing. In this case, there is a significant credit risk. And there is practically no secondary market. Bangladesh, Nicaragua, Romania, as well as the Ukrainian leasing market belong to this stage.

In the third stage (comprehensive financial leasing), there is an intensive development of the leasing market, its volumes and market penetration. This process is manifested in the emergence of a large number of entities providing an expanded range of services. Manufacturers and sellers of fixed assets are starting to create their leasing companies. Lessors reduce margin for lessees. At the same time, lessees are given the opportunity to choose between the lease object's redemption or the renewal of the lease term. Public authorities are beginning to actively pursue the stimulating policy, regulate leasing relations. The peculiarity of this stage is the lessors' interest in percentages, competition in operations volumes. Lessors begin to pay attention to the added value as well. At this stage, there are India, Pakistan, Panama, Peru, and El Salvador are at this stage.

The fourth stage (package of services, or operational/operating leasing) is formed when the com- petition intensifies in the leasing industry and the developed secondary market appears. For the vast majority of operating leases, there is a full complex of services, which is advantageous to the consumer. The emphasis is on the possibility of the lessee to return a fixed asset upon the expiry of the lease agreement. Lessees have the right to set their terms when signing agreements, which lessors have to agree. This feature characterizes leasing as a finished financial product. At the given stage of leasing development, there are Argentina, Belgium, Brazil, Denmark, Estonia, Israel, Indonesia, Ireland, Italy, Colombia, Mexico, Netherlands, Germany, Norway, Poland, Russia, Slovenia, Taiwan, Hungary, Finland, France, and Czech Republic (Smirnova, 2014).

The evolution from the fourth to the fifth stage (the stage of new products) comes with the further competition aggravation, technology transfer and creative search for lessees. Complicated leasing has a variety of options: termination, renewal and continuation of loans, technology upgrades. All this should make the leasing relationship flexible and adapted to various changes (financial, technological, etc.). Venture, complex leasing and securitization arise at this stage. Leasing markets of Canada, Australia and Japan belong to this stage. Characteristic features of the evolutionary introduction of leasing agreements in foreign countries are presented in Table 1.

The final stage of the leasing development is the sixth stage - the stage of maturity, which is inherent in calming down, reducing the number of introduced innovative products. The leasing transactions volume increase is influenced only by the growth of the economy. This stage provides the leasing industry consolidation in the form of absorptions, acquisitions, investment funds, joint ventures. While lowering profits, lessors increase their operational effectiveness, focusing on asset risk assessment features (instead of lending problems). Lessors are trying to attract customers with their knowledge of technics and technology. Leasing branches in the UK and the US are at the maturity stage.

Passing of six stages of leasing industry life cycle is also inherent in a separate country. In spite of the stage at which the market is located, there are 
Table 1. Characteristics of the leasing evolution stages in the world

Source: proposed by authors on the basis of Nair et al. (2004), Canada Market Review, Japan Market Review.

\begin{tabular}{|c|c|c|}
\hline Stage & Characteristic feature & The country where it is used \\
\hline Operating leasing & $\begin{array}{l}\text { It is provided for a short term that does not } \\
\text { involve the ownership transfer; the price consists } \\
\text { of the lease object's amortized cost and the } \\
\text { bank interest }\end{array}$ & All countries \\
\hline Simple financial leasing & $\begin{array}{l}\text { It is provided for a period of } 70-80 \% \text { of the } \\
\text { useful service life of the leased asset with the } \\
\text { subsequent right of redemption, therefore, taxes } \\
\text { charging is expected to be associated with the } \\
\text { ownership transfer }\end{array}$ & Bangladesh, Nicaragua, Romania, Ukraine \\
\hline $\begin{array}{l}\text { Comprehensive } \\
\text { financial leasing }\end{array}$ & $\begin{array}{l}\text { It contains all features of simple financial } \\
\text { leasing, but also includes services for equipment } \\
\text { maintenance and property risk insurance }\end{array}$ & India, Pakistan, Panama, Peru, El Salvador \\
\hline Operational leasing & $\begin{array}{l}\text { The leasing service contains a set of options - } \\
\text { insurance, service, installation, reverse leasing, } \\
\text { forfeiting, which are selected by each client } \\
\text { individually }\end{array}$ & $\begin{array}{l}\text { Argentina, Belgium, Brazil, Denmark, Estonia, } \\
\text { Israel, Indonesia, India, Italy, Columbia, Mexico, } \\
\text { Netherlands, Germany, Norway, Poland, Russia, } \\
\text { Slovenia, Taiwan, Hungary, Finland, France, United } \\
\text { Kingdom, Czech Republic }\end{array}$ \\
\hline Synthetic products & $\begin{array}{l}\text { It means synthetic instruments creation for } \\
\text { leasing loan financing without the involvement } \\
\text { of a bank loan }\end{array}$ & Great Britain, USA, Canada, Australia and Japan \\
\hline
\end{tabular}

leasing companies that only provide certain services (financial or operational leasing, venture leasing), such as in the United States. At the same time, Korea is the brightest example of being at one of the stages (stage of financial leasing). Given the global integration processes, the possibility of accelerated information exchange with the help of advanced technics and technology, one should expect a reduction in the lease life cycle duration.

The leasing market in Ukraine is at an initial stage, namely, at the second stage of its development - simple financial leasing. There are significant prospects for this area development, but this development is possible only by creating a favorable economic and legal environment. This is confirmed by the developed countries experience, as well as Poland, the Czech Republic, Hungary, Russia, which testifies to the significant revival of economic growth, fixed capital updating in a short term with the help of leasing (Pysarenko \& Netudy-Khata, 2010).

Today it is possible to distinguish two methods of leasing, which are most often observed in international practice. The first method is usually used by European companies and banks and it implies the creation of leasing companies in other countries. The second method of leasing involves performing international operations between lessors and lessees located in different countries and it is used when it comes to large lease objects, such as airplanes, trains, and vessels.
The biggest part of global leasing is concentrated in the "triangle": the USA - Western Europe - Japan. The comparative characteristics of providing leasing services in Ukraine and in the world are presented in Table 2 .

The comparative analysis of the leasing markets of Ukraine, the USA, Germany and Japan makes it possible to affirm that:

- the level of leasing development correlates with the level of the country's economy industrial sector development and influences the pace of strategically important markets development;

- foreign leasing organizations quickly and skillfully adapt to the real needs of the world economy, introducing the latest forms and methods of leasing operations provision and expanding the scope of its application;

- the implementation of privileges at the initial stage of leasing, aimed at stimulating its development. It is an extremely necessary and economically feasible measure for ensuring social and economic development of the state;

- machine building is the dominant sector of the economy, where the growth of leasing services and the share of leasing in other funding sources are the highest. 
Table 2. Comparative characteristics of leasing services provision in Ukraine and in the world

Source: generalized by authors based on (Bohdanchuk, 2014; Hryshchenko, 2006; Korniev, 2011; Onyshchuk, 2005).

\begin{tabular}{|c|c|c|c|c|}
\hline $\begin{array}{c}\text { Comparative } \\
\text { feature }\end{array}$ & USA & Germany & Japan & Ukraine \\
\hline $\begin{array}{l}\text { The use of leasing in } \\
\text { its modern sense }\end{array}$ & $\begin{array}{l}\text { The } 50 \text { s of the } 20 \text { th } \\
\text { century }\end{array}$ & 1962 & 1978 & $\begin{array}{l}\text { The 90s of the 20th } \\
\text { century }\end{array}$ \\
\hline $\begin{array}{l}\text { The stage of leasing } \\
\text { development }\end{array}$ & $\begin{array}{l}\text { Maturity of the leasing } \\
\text { market }\end{array}$ & $\begin{array}{l}\text { Package services, or } \\
\text { operating leasing }\end{array}$ & New leasing products & Simple finance leasing \\
\hline \multicolumn{5}{|c|}{ Characteristics of a financial lease agreement } \\
\hline $\begin{array}{l}\text { Lessee's investments in } \\
\text { the leased asset }\end{array}$ & $\begin{array}{l}\text { Only some } \\
\text { improvements }\end{array}$ & - & - & $\begin{array}{l}\text { Improvement of the } \\
\text { leased asset only with } \\
\text { the consent of the lessor }\end{array}$ \\
\hline $\begin{array}{l}\text { Term of the lease } \\
\text { agreement }\end{array}$ & $\begin{array}{l}\text { Less than } 80 \% \text { of useful } \\
\text { life }\end{array}$ & $40-90 \%$ of economic life & $\begin{array}{c}\text { Less than } 70 \% \text { of } \\
\text { economic life and } 60 \% \\
\text { if the term is more than } \\
10 \text { years }\end{array}$ & $\begin{array}{c}\text { More than } 75 \% \text { of } \\
\text { original cost }\end{array}$ \\
\hline $\begin{array}{l}\text { Availability of option } \\
\text { (right of redemption) }\end{array}$ & Not necessarily & $\begin{array}{l}\text { Intended cost of the } \\
\text { option coincides with } \\
\text { the value of the property } \\
\text { at the time of realization }\end{array}$ & $\begin{array}{l}\text { Intended options for } \\
\text { early completion, } \\
\text { updates and other } \\
\text { innovations }\end{array}$ & Not intended \\
\hline $\begin{array}{l}\text { Residual value of the } \\
\text { leased asset }\end{array}$ & Not less than $20 \%$ & - & Zero or nominal & - \\
\hline $\begin{array}{l}\text { The cost of leasing } \\
\text { payments }\end{array}$ & $\begin{array}{l}\text { More or equal to } 90 \% \text { of } \\
\text { the leased asset market } \\
\text { value }\end{array}$ & $\begin{array}{l}\text { It covers the cost of } \\
\text { production, acquisition } \\
\text { and other current } \\
\text { expenses }\end{array}$ & $\begin{array}{l}\text { Approximately equal } \\
\text { to the total cost of } \\
\text { acquiring property }\end{array}$ & $\begin{array}{l}\text { Equals or exceeds the } \\
\text { value of the leased asset }\end{array}$ \\
\hline $\begin{array}{l}\text { Consideration of } \\
\text { financial leasing in the } \\
\text { taxation system }\end{array}$ & $\begin{array}{l}\text { Leasing is a sale of } \\
\text { services. The entire lease } \\
\text { payment is recognized } \\
\text { by the lessor as gross } \\
\text { revenues, and the lessee } \\
\text { as gross expenses }\end{array}$ & $\begin{array}{l}\text { Leasing is a sale of } \\
\text { property. The share of } \\
\text { the lease payment that } \\
\text { repays the principal } \\
\text { value of the leased } \\
\text { asset is not the profit } \\
\text { of the lessor and is } \\
\text { not recognized as } \\
\text { expenditures by the } \\
\text { lessee }\end{array}$ & $\begin{array}{l}\text { Leasing is } \\
\text { a sale of services }\end{array}$ & $\begin{array}{l}\text { Leasing is } \\
\text { a sale of property }\end{array}$ \\
\hline \multicolumn{5}{|c|}{ Characteristics of leasing activity } \\
\hline Privileges & $\begin{array}{c}\text { Accelerated } \\
\text { depreciation, investment } \\
\text { tax incentives }\end{array}$ & $\begin{array}{l}\text { Abolished by the } \\
\text { government after } \\
\text { significant abuses }\end{array}$ & Not intended & $\begin{array}{l}\text { Accelerated } \\
\text { depreciation }\end{array}$ \\
\hline $\begin{array}{l}\text { Dominant sectors of } \\
\text { the economy where } \\
\text { leasing is being } \\
\text { developed }\end{array}$ & $\begin{array}{l}\text { Motor vehicles, planes, } \\
\text { medical equipment }\end{array}$ & $\begin{array}{l}\text { Motor vehicles, } \\
\text { machinery and } \\
\text { equipment, real } \\
\text { estate (in particular } \\
\text { land), technology } \\
\text { of production } \\
\text { intensification and } \\
\text { information provision }\end{array}$ & $\begin{array}{l}\text { Equipment for } \\
\text { information and } \\
\text { communication } \\
\text { processing, equipment } \\
\text { for accounting works } \\
\text { automation }\end{array}$ & $\begin{array}{c}\text { Water and rail transport, } \\
\text { cars, transport } \\
\text { passenger and cargo } \\
\text { transportation, airplanes }\end{array}$ \\
\hline $\begin{array}{l}\text { Leading leasing } \\
\text { organizations }\end{array}$ & $\begin{array}{c}\text { Security Pacific Consider } \\
\text { Corp, Bank Amerilase } \\
\text { Group }\end{array}$ & $\begin{array}{c}\text { Mietfinanz } \mathrm{GmbH} \text {, Gefa } \\
\text { Leasing } \mathrm{GmbH}\end{array}$ & $\begin{array}{l}\text { Gentury Leasing System, } \\
\text { Orix Corporation }\end{array}$ & $\begin{array}{c}\text { First leasing company, } \\
\text { Ukrleasing }\end{array}$ \\
\hline $\begin{array}{l}\text { Legislation that } \\
\text { regulates leasing } \\
\text { relations }\end{array}$ & $\begin{array}{l}\text { Leasing agreement and } \\
\text { civil and commercial } \\
\text { law }\end{array}$ & $\begin{array}{l}\text { Litigation and tax } \\
\text { authorities' decisions }\end{array}$ & General law norms & Special laws \\
\hline $\begin{array}{l}\text { Characteristic } \\
\text { features }\end{array}$ & $\begin{array}{l}\text { 1. Active occupation } \\
\text { of the global leasing } \\
\text { market. } \\
\text { 2. Fighting fake leasing } \\
\text { contracts. } \\
\text { 3. Consolidation of the } \\
\text { leasing market, in the } \\
\text { form of acquisitions, } \\
\text { absorptions, joint } \\
\text { ventures or alliances and } \\
\text { funds. } \\
\text { 4. Low profit rates, } \\
\text { increased operational } \\
\text { efficiency. } \\
5 \text {. General decrease in } \\
\text { leasing development }\end{array}$ & $\begin{array}{l}\text { 1. Dynamic } \\
\text { development of various } \\
\text { types of leasing. } \\
\text { 2. Most leasing } \\
\text { operations are carried } \\
\text { out by organizations of } \\
\text { the National federative } \\
\text { association LK. } \\
\text { 3. Fierce competition in } \\
\text { the leasing market. } \\
\text { 4. Active development } \\
\text { of the secondary market. } \\
\text { 5. Growth of } \\
\text { multinational lessees' } \\
\text { demand. } \\
\text { 6. Leasing organizations } \\
\text { provide a full range of } \\
\text { related services }\end{array}$ & $\begin{array}{l}\text { 1. The use of economic } \\
\text { methods of stimulating } \\
\text { leasing, i.e. providing } \\
\text { cheap long-term loans. } \\
\text { 2. Expansion of activity } \\
\text { on the foreign market. } \\
\text { 3. Leasing is provided } \\
\text { by specialized } \\
\text { organizations. } \\
\text { 4. Creating of leasing } \\
\text { organizations ordered by } \\
\text { whole markets. } \\
\text { 5. Emergence of new } \\
\text { products: securitization, } \\
\text { venture and } \\
\text { comprehensive leasing }\end{array}$ & $\begin{array}{l}\text { 1. Stabilization of leasing } \\
\text { activities. } \\
\text { 2. Limited competition } \\
\text { between leasing } \\
\text { organizations and severe } \\
\text { competition on banks' } \\
\text { part. } \\
\text { 3. Active penetration } \\
\text { of foreign organizations } \\
\text { into the leasing market. } \\
\text { 4. Emergence of } \\
\text { problems with leasing } \\
\text { activities financing. } \\
\text { 5. Undeveloped } \\
\text { secondary market of } \\
\text { fixed assets }\end{array}$ \\
\hline
\end{tabular}


During 2010-2016, German leasing organizations expand to the international market, develop cooperation, first of all, with its neighbors in the European Union, the Arab world, and more recently with Ukraine, offering competitive leasing services with a wide range of possible leasing items. Although qualitative characteristics of German leasing services are still inferior to American and Japanese ones, which are provided by inter-leasing organizations, now German leasing services exceed the latter by the growth rates of leasing operations.

In Japan, leasing arose much later than in other developed countries, but significant and regular investments in science and technology have contributed to the rapid development of new technologies and have affected the pace of the leasing market and recently led the Japanese leasing market to the fifth stage of the global leasing market evolution - the stage of new leasing products (Frydel, 2012).

The driving forces behind the evolution of leasing were hard competition, leasing organizations' creativity and the continuous development of the latest high-value types of equipment and technology. Operational leasing as a financial product becomes very advanced, with complex options for leasing expiring, early termination options, loans renewals and extending, technology upgrades and other innovations. All these factors create new opportunities for flexible adaptation of the lease term to financial, economic and technological changes of the lessee.

If we analyze the peculiarities of the financial and credit mechanism for performing leasing operations in the world, today the main sources of such operations are:

- bank loans;

- funds and certificates of institutional investors;

- funds and certificates of venture capital investors;

- pools of securities provided with assets, which is a leasing agreement.

As for Ukraine, today the most widespread source of leasing financing is bank loan, which is characterized by a rather high level of interest and imper- fect legislation in the field of tax accounting and auditing. In this regard, we consider the alternative experience of financial and credit provision of leasing operations, which is spread in developed countries of the world.

For example, Japanese leasing organizations use instruments and forms of financial and credit support for leasing transactions, such as securitization, venture leasing and comprehensive leasing.

Securitization is a shift in the borrowing market from classical bank lending to financing on the impoverished money market and capital market through securities issuance. The basic principles of its implementation are true sale, synthetic securitization and whole business. The concept of true sales securitization means that a financial company called the originator sell assets to a special purpose vehicle (SPV) that provides financing for the acquisition of assets through the securities issue and its placement on the capital market.

In the case of synthetic securitization, the originator company does not sell assets, but transfers the loss risks associated with certain assets to the target company or bank for the respective premium or fee. During the "whole business" securitization principle, a specialized legal entity provides a secured loan to the originator. To fill the loan, the target company uses funds from the bonds placement in the capital market, while the originator provides its assets to investors-bondholders as securement.

The same practice is also applied by Canada at the state level. The Canadian Federal Government continues supporting the leasing securitization through financing the Funding Platform for Independent Lenders (F-PIL) program. Within the program, the public consortium was created between BDC and TAO Asset Management, funded by independent small and medium-sized financial and leasing companies that directly finance leasing loans for the mobile and commercial equipment purchase. This practice contributed to the restoration of real business leasing financing, which declined by $20 \%$ in 2006 due to interest rates approaching to the near-zero level, but in 2016, the growth was already 3.6\% (Canada Market Review). 
Given the level of interest rates in Ukraine, the volume of investment growth in leasing debt instruments is going to be several times higher than under the present financial conditions of Canada. But the securitized asset may carry a significant systemic risk to the national financial system. However, European countries have revised their attitude towards securitization as a factor of financial and banking instability, and begin to treat it as a part of the anti-crisis strategy. It is believed that properly structured and regulated securitization can diversify funding sources of banks and transfer credit risk to non-bank financial institutions, thereby improving capital performance of the bank, which in turn will increase the opportunities for lending to the real economy. In addition, it is believed that it can complement other long-term wholesale sources of funding for the real economy, including for small and mediumsized enterprises.

Another financing source for leasing operations is the institutional investors' funds and certificates. Institutional investors are highly interested in investments aimed at implementing projects with medium-term period. Financing of leasing aircraft vehicles is an example. German lease market is the leader in this sector. Nowadays, private pension funds are major institutional investors in leasing loan pools financing in Germany, and as of January 1, 2016, insurance companies that specialize in long-term insurance also joined this sector (in connection with regulatory limitations European Solvency II adoption) (Statistics of Lease Europe Association).

Together with an increase of institutional investors' interest in debt instruments and capital as the financing source for agreements in the aviation industry, there is also a positive trend regarding the growth of leasing loans financing by lessors' mortgage bonds. In particular, the expected annual growth of the airspace market in Germany is going to be over $50 \%$ by 2030 , representing $3.3 \%$ of annual growth (taking into account the risk of traffic outflow to the East European low-cost lines) (Statistics of Lease Europe Association). According to experts, this situation will contribute to an increase in the number of leasing transactions during aviation vessels purchase.
At the same time, due to the non-implementation of the Cape Town Convention, which governs the international guarantees provision for a solid implementation of rolling stock lease agreements and specific aviation equipment, there are some difficulties in international leasing transactions implementation in the German market (Canada Market Review). As for now, 70 countries have supported and ratified this Convention, therefore, Ukraine as a leading aircraft manufacturer should join the Cape Town process and the European Solvency II mechanism in order to protect the interests of both lessors and lessees as well as leasing object suppliers, as the Ukrainian producer is currently closed to the global market due to the lack of international leasing financing.

Venture capital investors' funds are the effective source of leasing operations financing. According to experts, venture business provides about $40 \%$ of all leasing transactions financing in the US economy. According to the European Private Equity and Venture Capital Association, about 50\% of all Western European leasing operations venture financing is currently carried out by UK funds (Smirnova, 2014).

Venture financing as a separate component of financial and credit mechanism for providing leasing operations allows to ensure the management efficiency, to reduce transactional costs connected with leasing projects operation and financing. It should be noted that venture capital can be formed at the expense of firms and venture capital funds' money; money of specialized funds for support of small firms working in the scientific and technical sphere; investment companies' money; institutional financial investors' money (pension funds and insurance companies); non-financial companies' money; industrial and financial groups' money; and national and commercial banks' money.

According to world practice, the main difference between venture financing of leasing operations in Western European countries compared to the USA is a higher specific share of banks' money in the venture capital. In addition, government institutions, universities and other organizations participate in financing risky leasing projects. 
The world experience in the leasing operations financing with the help of venture capital with its risk distribution can be one of the most effective ways of the capital attraction for economic development, and can be considered as a real way for the investment market development and the emergence of the innovative Ukrainian economy.

The European Bank for Reconstruction and Development (EBRD) is the main investor of venture financing in Ukraine. In addition, innovative processes are financed at the expense of foreign companies' and individuals' funds, free funds of Ukrainian financial-industrial groups. We can affirm that venture financing is at an initial stage and does not sufficiently facilitate the search for leasing activities capital sources. Therefore, the leasing operations venture financing development in Ukraine should become one of the priority directions of the state policy in the field of innovations and the stipulation for leasing activity activation. Loan capital in the innovation activities financing involves the domination of bank or commercial loans obtaining. However, the advantage of leasing is that it offers risky financing for enterprises without credit history and does not require the collateral for separate positions. Leasing offers to Ukraine product solutions and improvement of financing both for high-tech branches of aircraft industry and for the agro-industrial complex that is for those sectors of the economy in which Ukraine has strong positions.

The main reasons that hold back leasing operations financing at the expense of venture capital in Ukraine are:

- instability in the country, which hinders the venture business development;

- lack of financial resources and the constant threat of inflation;

- undeveloped securities market;

- poor information support of venture business;

- insufficient economic incentives for attracting venture capital.

Thus, venture financing of leasing operations in Ukraine needs a stable low inflation rate, a predictable exchange rate, stock market development with the state assistance in issuing guarantees on credit swaps under venture leasing loans. It is al- so necessary to develop the existing system of financial instruments rating on the basis of already existing authorized agencies (Rating agencies. Authorized rating agencies included into the State Register of Authorized Rating Agencies). The rating assessment should provide unbiased information on the debtor's solvency under the securitized asset and correlate with the guarantee premium on the issued debt instrument.

Another impetus for the financial and credit mechanism for providing leasing operations development in Ukraine may be the secondary leasing market development that is currently underdeveloped in Ukraine, Moldova, Russia and Belarus and is available only on the rental market of movable property such as cars, tractors and combine harvesters. Since the leasing object is the lease loan collateral, the equipment secondary market is an essential element in reducing the risk of the debt underfunding. Therefore, the absence of a developed secondary market increases the lessors' activity riskiness by several times. As a result, leasing companies are more vulnerable to the risk of changing the price of equipment than other financial and credit institutions.

Ukraine should also consider introducing a European investment plan for the leasing industry, according to which investing in emerging economies involves the implementation of an innovative policy on equipment resale in case of borrower default. The European plan allows the lessee to sell the equipment to the European operator at the best price. Under this approach, the operating costs and depreciation are still leased by the lessee rather than the European fund, while allowing the client to continue to generate profits from the useful equipment use (Nair et al., 2004).

Expanding tools and methods of leasing operations financing and thereby increasing the Ukrainian leasing market capitalization can be achieved through the relevant appeal submission from the Ukrainian association of lessors to the European Commission. According to the JUNCKER PLAN launched in June 2015 by the European Commission, the investment recovery in the innovation industry of European countries should take place, which decreased by $15 \%$ in 2017 , to the level of 2007. 
Table 3. Types of loans granted to support the leasing industry in the Eurozone

Source: World Leasing Yearbook, 2017 (The Juncker Plan and other support for leasing in Europe).

\begin{tabular}{|c|c|c|c|}
\hline Program & Type of loan & $\begin{array}{c}\text { Potential recipient } \\
\text { of a loan }\end{array}$ & Lessor \\
\hline $\begin{array}{l}\text { Loan of European Investment Bank } \\
\text { for intermediaries }\end{array}$ & Loans to financial intermediaries & All lessors & $\begin{array}{l}\text { European Investment } \\
\text { Bank (EIB) }\end{array}$ \\
\hline $\begin{array}{l}\text { Target long-term refinancing } \\
\text { loan (TLTRO-Targeted Long-term } \\
\text { Refinancing Operation) }\end{array}$ & $\begin{array}{l}\text { Refinancing loans to commercial banks } \\
\text { of the Eurosystem }\end{array}$ & Eurozone banks & $\begin{array}{l}\text { European Central Bank } \\
\text { (ECB) }\end{array}$ \\
\hline COSME & $\begin{array}{l}\text { Portfolio guarantees for leasing } \\
\text { companies }\end{array}$ & All lessors & $\begin{array}{l}\text { European Investment } \\
\text { Fund (EIF) }\end{array}$ \\
\hline InnovFin & $\begin{array}{l}\text { Guarantees for loans granted to } \\
\text { SMEs and small companies with low } \\
\text { capitalization }\end{array}$ & All lessors & $\begin{array}{l}\text { European Investment } \\
\text { Fund (EIF) }\end{array}$ \\
\hline $\begin{array}{l}\text { Portfolio of first loss compensation } \\
\text { guarantees (FLPG - First Loss } \\
\text { Portfolio Garantees) }\end{array}$ & $\begin{array}{l}\text { Guarantees for SME loans that have } \\
\text { been credited with more favorable } \\
\text { terms or benefits }\end{array}$ & $\begin{array}{l}\text { Characterized by } \\
\text { national level }\end{array}$ & $\begin{array}{l}\text { European Investment } \\
\text { Fund (EIF) and National } \\
\text { Agencies }\end{array}$ \\
\hline Initiatives for SMEs & $\begin{array}{l}\text { Guarantees for SME loans that have } \\
\text { been credited with more favorable } \\
\text { terms or benefits }\end{array}$ & $\begin{array}{l}\text { Characterized by } \\
\text { national level }\end{array}$ & $\begin{array}{l}\text { European Investment } \\
\text { Fund (EIF) and National } \\
\text { Agencies }\end{array}$ \\
\hline Structural funding program & $\begin{array}{l}\text { Guarantees for loans in the leasing } \\
\text { company's portfolio, which will be } \\
\text { repaid firstly in case of default }\end{array}$ & All lessors & $\begin{array}{l}\text { European Investment } \\
\text { Bank (EIB) }\end{array}$ \\
\hline $\begin{array}{l}\text { Securitized asset for loans granted } \\
\text { to SMEs (SISI-SME Initiative } \\
\text { Securitization Instrument) }\end{array}$ & $\begin{array}{l}\text { Guarantees for loans in the leasing } \\
\text { company's portfolio, which will be } \\
\text { repaid firstly in case of default }\end{array}$ & Banks & $\begin{array}{l}\text { European Investment } \\
\text { Bank (EIB) }\end{array}$ \\
\hline $\begin{array}{l}\text { AGRI - Agricultural Guarantee } \\
\text { Fund }\end{array}$ & $\begin{array}{l}\text { Guarantees for loans granted to } \\
\text { agribusiness, forestry and farms }\end{array}$ & All lessors & $\begin{array}{l}\text { European Investment } \\
\text { Bank (EIB) }\end{array}$ \\
\hline
\end{tabular}

The European Fund for Strategic Investment (EFSI) is the part of the European Investment Fund (EIF), which promotes investment in the private sector through the investment guarantees placement, as well as finance guarantees that are part of the lessors financing program, which lend money to small and medium-sized enterprises (SMEs) (Table 3).

Around EUR 5 billion were provided from EFSI through 60 investment agreements with lessors. These deals are not limited to direct investments and guarantees, but are done for refinancing loans granting to commercial banks of Eurozone TLTRO. Within this program, about 17,000 small and medium-sized businesses received leasing financing, which allowed to create additional 750,000 jobs.

Thus, the implementation of world experience in the financial and credit mechanism for providing leasing operations functioning will facilitate the leasing financing, provide an investment inflow in this sector, have a positive impact on the financial stability of leasing companies and the financial and credit sector in general and will contribute to the leasing activity development in Ukraine.

\section{CONCLUSION}

Based on the specific characteristics of the six stages of leasing development in the world (rent, simple financial leasing, comprehensive financial leasing, service package (operational leasing), the stage of new products, maturity) it was found that Ukraine is at the second stage, named simple financial leasing. Today, the country has significant prospects for leasing development, but first of all, it is necessary to create a favorable economic and legal environment. Secondly, to diversify financing sources of leasing operations, namely: to use funds and certificates of institutional investors and venture capital investors, security pools provided with assets, which is a leasing agreement. Third, to introduce such instruments and forms of financial and credit support for leasing transactions, namely: securitization, venture leasing, complex and operational leasing. At the same time, the secondary leasing market development in Ukraine (which is currently underdeveloped and available only on the rental market for movable property such as cars, tractors and combines) will reduce the leasing companies vulnerability to the risk of changing equipment prices. 


\section{REFERENCES}

1. Bohdanchuk, O. L. (2014). Порівняльна характеристика видів лізингу [Porivnialna kharakterystyka vydiv lizynhu]. Управління розвитком [Upravlinnia rozvytkom], 4, 41-44. Retrieved from http://nbuv.gov.ua/ UJRN/Uproz_2014_4_17

2. Canada Market Review. World Leasing Yearbook (2017). Retrieved from http://www. world-leasing-yearbook.com/ wp-content/uploads/2017/01/ WLY2017_Canada.pdf

3. Chushak, A. M., \& Mykulyak, J. R. (2014). The Nature and Signaficance of Financial Leasing in Ukraine, Problems of Development. Вісник Національного університету “Львівська політехніка" [Visnyk Natsionalnoho universytetu "Lvivska politekhnika"], 790, 57-62. Retrieved from http://ena.lp.edu.ua:8080/handle/ $\mathrm{ntb} / 25172$

4. Frolov, S., Strilec, V., \& Balatskyi, Ye. (2017). Foresight technologies in financial provision of small business in Ukraine. Problems and Perspectives in Management, 15(1-1), 200-209. http://dx.doi. org/10.21511/ppm.15(11). 2017.07

5. Frydel, V. I. (2012).

Характеристика левериджлізингу: зарубіжний досвід та можливості застосування в Україні [Kharakterystyka leverydzh-lizynhu: zarubizhnyi dosvid ta mozhlyvosti zastosuvannia v Ukraini]. Формування ринкових відносин в Україні [Formuvannia rynkovykh vidnosyn v Ukraini], 10, 53.

6. Growth Internal market, Industry, Entrepreneurship and SMEs. European Commission. Retrieved from http://ec.europa.eu/growth/ smes/business-friendlv-environment/performance-review-2016

7. Hontar, D., Opeshko, N., \& Kolodizieva, S. (2016). Forecasting the development of leasing market (on the example of Ukraine). Problems and Perspectives in Management, 14(4-1), 264-272. http://dx.doi.org/10.21511/ ppm.14(4-1).2016.16
8. Hryshchenko, O. (2006). Фінансовий лізинг: історія, сучасність та перспективи розвитку [Finansovyi lizynh: istoriia, suchasnist ta perspektyvy rozvytku]. Юридичний журнал [Yurydychnyi zhurnal], 3, 61-68.

9. Japan Market Review. World Leasing Yearbook (2017). Retrieved from http://www. world-leasing-yearbook.com/ wp-content/uploads/2017/01/ WLY2017_Japan.pdf

10. Komarov, V. V. (2002). Investments and leasing activities in CIS countries. Russian magazine in Economics, 1, 87-90.

11. Korniev, V. L. (2011). Сутність та види лізингу [Sutnist ta vydy lizynhu]. Держава та регіони. Сер.: Економіка та підприємництво [Derzhava ta rehiony. Ser.: Ekonomika ta pidpryiemnytstvo], 1, 108-112.

12. Lisovska, N. (2017). Розвиток ринку лізингових послуг [Rozvytok rynku lizynhovykh posluh]. Товари і ринки [Tovary $i$ rynky], 1, 29-36.

13. Mykhalchyk, L. V., \& Kryvoruchko, Ye. О. (2015). Міжнародний досвід використання лізингових відносин в Україні [Mizhnarodnyi dosvid vykorystannia lizynhovykh vidnosyn v Ukraini]. Вісник Житомирського державного технологічного університету. Серія: Економічні науки [Visnyk Zhytomyrskoho derzhavnoho tekhnolohichnoho universytetu. Seriia: Ekonomichni nauky], 3, 78-84.

14. Nair, A., Kloeppinger-Todd, R., \& Mulder, A. (2004). Leasing. An Underutilized Tool in Rural Finance. Agricuture and Rural Development Discussion Paper 7. The International Bank of Reconstruction and Development. The World Bank. Washington, DC, 57.

15. Nikolaieva, S. P., \& Puhachenko, О.В. (2014). Лізингова діяльність: історія виникнення та розвитку [Lizynhova diialnist: istoriia vynyknennia ta rozvytku]. Наукові праці Кіровоградського національного технічного університету. Економічні науки [Naukovi pratsi Kirovohradskoho natsionalnoho tekhnichnoho universytetu. Ekonomichni nauky], 26, 255-265.

16. Olugbenga, S., \& Mashigo, P. (2017). The impact of microfinance on microenterprises. Investment Management and Financial Innovations, 14(3), 82-92.

17. Onyshchuk, Ya. V. (2005). Розвиток лізингу в Україні [Rozvytok lizynhu v Ukraini]. Фінанси України [Finansy Ukrainy], 7, 106-113.

18. Pysarenko, M. M., \& Netudykhata, К. Р. (2010). Розвиток лізингу в контексті європейських тенденцій [Rozvytok lizynhu v konteksti yevropeiskykh tendentsii]. Держава та регіони Сер.: Економіка та підприємництво [Derzhava ta rehiony Ser.: Ekonomika ta pidpryiemnytstvo], 6, 57-60.

19. Smirnova, O. O. (2014). Лізинговий бізнес в Україні: сучасний стан і можливості застосування іноземного досвіду [Lizynhovyi biznes v Ukraini: suchasnyi stan i mozhlyvosti zastosuvannia inozemnoho dosvidu]. Фінанси, облік і аудит [Finansy, oblik i audyt], 1, 128-140.

20. Statistics of LeaseEurope Association. Annual Survey (2015). Retrieved from http://www.leaseurope.org/uploads/documents/ stats/European\%20Leasing\%20 Market\%202015.pdf

21. Survey on the access to finance of enterprises. Retrieved from http:// ec.europa.eu/docsroom/documents/20369/attachments/1/translations/en/renditions/native

22. The Juncker Plan and other support for leasing in Europe. Retrieved from: http://www.world-leasingyearbook.com/wp-content/ uploads/2017/01/WLY2017_Junker_Plan.pdf

23. Vakhitov, D., \& Zamaletdinov, A. (2015). Leasing as a factor of economic growth. $2^{\text {nd }}$ Global conference on business, economics, management and tourism, 30-31 
October 2014, Prague, Czech Republic, 6.

24. Vasin, Yu. (2016). Підсумки та перспективи роботи союзу “Сертифіковані спеціалісти лізингу» [Pidsumky ta perspektyvy roboty soiuzu "Sertyfikovani spetsialisty lizynhu”]. Офіційний сайт Союзу “Сертифіковані спеціалісти 3 лізингу”. Retrieved from http:// www.leasepro.org.ua/Data/Documents/Issue4_Aug2016.pdf
25. Weidner, D. J. (2000). Synthetic Leases: Structured Finance, Financial Accounting and Tax Ownership. Journal of Corporation Law, 3(25), 445-487. Retrieved from http://ir.law.fsu.edu/articles/134

26. Основні показники діяльності фінансових компаній та лізингодавців [Osnovni pokaznyky diialnosti finansovykh kompanii ta lizynhodavtsiv]. Retrieved from https://nfp.gov.ua/
files/17_Dep_Repetska/FK_4\%20 \%D0\%BA\%D0\%B2_2016.pdf

27. Рейтингові агентства. Уповноважені рейтингові агенства, включені до Державного реєстру уповноважених рейтингових агентств [Reitynhovi ahentstva. Upovnovazheni reitynhovi ahenstva, vkliucheni do Derzhavnoho reiestru upovnovazhenykh reitynhovykh ahentstv]. Retrieved from http:// www.nssmc.gov.ua/fund/ rateagencies 